\title{
Abnormal sodium current properties contribute to cardiac electrical and contractile dysfunction in a mouse model of Myotonic Dystrophy type 1
}

Running title: Sodium current in myotonic dystrophy type 1.

\section{Authors:}

Vincent Algalarrondo ${ }^{\mathrm{a}, \mathrm{d}, *}$, Karim Wahbi ${ }^{\mathrm{b}, \mathrm{c}, *}$, Frédéric Sebag ${ }^{\mathrm{a}}$, Geneviève Gourdon ${ }^{\mathrm{e}, \mathrm{f}}$, Chérif Beldjord $^{\mathrm{g}, \mathrm{h}}$, Kamel Azibi $^{\mathrm{h}}$, Elise Balse ${ }^{\mathrm{a}}$, Alain Coulombe ${ }^{\mathrm{a}}$, Rodolphe Fischmeister ${ }^{\mathrm{d}}$, Bruno Eymard $^{\mathrm{b}}$, Denis Duboc ${ }^{\mathrm{b}, \mathrm{c}, \mathrm{o}}$, Stéphane N Hatem ${ }^{\mathrm{a}, \mathrm{o}}$ *, $\circ$ these authors contributed equally to this work

\section{From:}

a. INSERM UMRS-956, Pierre and Marie Curie University, Institute of Cardio-metabolism and nutrition (ICAN), Paris, France

b. Myology Institute, Pitié-Salpêtrière Hospital, Pierre and Marie Curie University, Paris, France

c. Cardiology Division, Cochin Hospital, Paris Descartes University, Paris, France

d. INSERM U-769, Labex Lermit, Chatenay Malabry, France

e. INSERM U781, Broussais Hospital, Paris, France

f. Université Paris Descartes-Sorbonne Paris Cité, Institut Imagine, Paris, France

g. INSERM Unit 567, Cochin Institute, CNRS UMR 8104, Paris, France

h. Biochemistry et molecular genetic laboratory, Cochin Hospital, Paris, France

\section{Corresponding author:}

Vincent ALGALARRONDO

INSERM UMRS-956, Pierre and Marie Curie University, Paris 6

91, boulevard de l'Hôpital - 75634 PARIS Cedex 13 - FRANCE

e-mail: vincent.algalarrondo@gmail.com

Tel: +33684440922

Fax: +33145374672

\section{Keywords:}

Steinert disease, Myotonic dystrophy type 1, conduction disorders, transgenic mice, electrophysiology, arrhythmia basic study, sodium current channelopathy. 


\section{Summary:}

Myotonic dystrophy type 1 (DM1) is the most common neuromuscular disorder and is associated with cardiac conduction defects. However, the mechanisms of cardiac arrhythmias in DM1 are unknown. We tested the hypothesis that abnormalities in the cardiac sodium current $\left(I_{\mathrm{Na}}\right)$ are involved, and used a transgenic mouse model reproducing the expression of triplet expansion observed in DM1 (DMSXL mouse). The injection of the class-I antiarrhythmic agent flecainide induced prominent conduction abnormalities and significantly lowered the radial tissular velocities and strain rate in DMSXL mice compared to WT. These abnormalities were more pronounced in 8month-old mice than in 3-month-old mice. Ventricular action potentials recorded by standard glass microelectrode technique exhibited a lower maximum upstroke velocity $[\mathrm{dV} / \mathrm{dt}]_{\max }$ in DMSXL. This decreased $[\mathrm{dV} / \mathrm{dt}]_{\max }$ was associated with a 1.7 fold faster inactivation of $I_{\mathrm{Na}}$ in DMSXL myocytes measured by the whole-cell patch-clamp technique. Finally in the DMSXL mouse, no mutation in the SCN5A gene was detected and neither cardiac fibrosis nor abnormalities of expression of the sodium channel protein were observed. Therefore, alterations in the sodium current markedly contributed to electrical conduction block in DM1. This result should guide pharmaceutical and clinical research towards better therapy for the cardiac arrhythmias associated with DM1. 


\section{Introduction}

Myotonic dystrophy type 1 (DM1), also known as Steinert's disease, is the most common inherited neuromuscular disease in adults (Ashizawa and Epstein, 1991). DM1 is a genetic disorder caused by the expansion of triplet repeats (CTG)n in the 3' region of the DMPK gene (Mahadevan et al., 1992). The main mechanism leading to phenotypical abnormalities of DM1 is the nuclear accumulation of mutant mRNAs causing aberrant alternative splicing of multiple pre-mRNAs (Amack et al., 1999; Mankodi et al., 2000). Cardiac electrical disturbances such as atrioventricular conduction blocks represent the most frequent cardiac manifestation of DM1 with major impacts on clinical outcomes, as up to $1 / 3$ of patients die suddenly (de Die-Smulders et al., 1998; Groh et al., 2008; Mathieu et al., 1999; Wahbi et al., 2012a; Wahbi et al., 2012b). However, mechanisms linking constitutive CTG expansion and cardiac phenotypes in DM1 patients are not known. In two distinct mouse models of DM1, atrioventricular conduction disturbances could be recorded a few days after inducing the expansion of the CTG triplet (Mahadevan et al., 2006; Wang et al., 2007). These studies point to alterations in cardiac conduction and excitability properties as an early event in the constitution of the DM1 associated cardiopathies.

The present study was undertaken to examine the mechanisms underlying the cardiac phenotype of DM1 using the mouse model that constitutively expresses the human DM1 locus under the regulation of its own promoter and its cis regulatory elements: the DMSXL mouse model. The originality of this model lies on the pattern of expression of the DMPK gene in DMSXL which is similar to DM1 patients including a high level of expression in the heart (Huguet et al., 2012). This model reproduces the main clinical characteristics observed in the human disease including reduced muscle strength, lower motor performances, peripheral neuropathy and respiratory impairments (Huguet et al., 2012; Panaite et al., 2011; Panaite et al., 2013). However, nothing is known about the cardiac phenotype of the DMSXL mouse.

Using a combination of physiological and pharmacological approaches, we provide evidence 
for reduced cellular excitability of the ventricular myocardium in the DMSXL mouse which appear to be due to anomalies related to the sodium current $\left(I_{\mathrm{Na}}\right)$ and which could account for the electrical and contractile dysfunctions seen in DM1 cardiopathy.

\section{Results}

\subsection{Enhanced sensitivity to flecainide of transgenic DMSXL mice}

Since in DM1 conduction disorders are known to progress with age (Groh et al., 2008), electrocardiographic and echocardiography analysis were performed on 3-month-old and 8-monthold mice. As previously described, DMSXL mice showed a growth retardation as indicated by a smaller size compared to WT (at 3 months, $19 \pm 3 \mathrm{~g}$ vs. $26 \pm 1 \mathrm{~g} ; P<0.0001, \mathrm{n}=11$ and at 8 months, $22 \pm 1$ g vs. $30 \pm 1 \mathrm{~g} ; P<0.0001, \mathrm{n}=11)$. DMSXL and WT mice showed the same heart weight / body weight ratio $(9 \pm 1 \%, \mathrm{n}=11$ in each group $)$.

\subsubsection{Electrocardiographic measurements}

At baseline, the ECG measurements were not different between WT and DMSXL mice (Figure 1A; Table 1). In order, to unmask clinically silent electrical conduction abnormalities, we used the class-I antiarrhythmic agent flecainide. In all mice studied, flecainide prolonged the duration of the P wave, the PR interval, the QRS complex and the corrected QT interval. At 3 months, DMSXL mice had longer QRS complexes than WT under flecainide, whereas the other parameters (P wave, PR interval, QTc interval) did not differ (Table1). In contrast, at 8 months, the effects of flecainide on ECG parameters were more pronounced in DMSXL mice as indicated by the marked prolongation of the ECG intervals measured 16 min after flecainide injection (Table 1). In addition, 6 out of 9 DMSXL mice $(67 \%)$ developed second or third degree AV block after flecainide injection whereas none did in the WT group $(P=0.009$, Figure $1 \mathrm{~A})$. This high prevalence of AV block prevented the measurements of the PR interval and the heart rate in 8-month-old mice under 
flecainide. These results indicated enhanced sensitivity to sodium channel blocker in 8-month-old DMSXL mice.

\subsubsection{Myocardial function using conventional echocardiography and Tissue Doppler}

\section{imaging}

The cardiac function of DMSXL mice was investigated by echocardiography (Figure 1B; Table 2).

The size and the systolic function of the left ventricle did not differ between WT and DMSXL mice, both at 3 and 8 months. To further examine the contractile properties of DMSXL hearts, we measured endocardial $V_{\text {endo }}$ and epicardial $V_{\text {epi }}$ tissue velocities and strain rate (SR) in order to detect discrete myocardial dysfunction (Koshizuka et al., 2013). At 3 months, WT and DMSXL mice had similar tissue velocities $\left(\mathrm{V}_{\text {endo }}, \mathrm{V}_{\text {epi }}\right)$ and strain rate (SR) (Table 2). In order to unmask cardiac dysfunction in 3-month-old DMSXL mice, we studied the effects of flecainide on echocardiographic parameters. Flecainide had no effect on LV size and left ventricular ejection fraction. In contrast, after injection of flecainide in 3-month-old mice, $\mathrm{V}_{\text {endo, }}, \mathrm{V}_{\text {epi }}$ and $\mathrm{SR}$ were significantly decreased in DMSXL mice (Table 2). Interestingly, at 8 months, $\mathrm{V}_{\text {endo }}, \mathrm{V}_{\text {epi }}$ and $\mathrm{SR}$ parameters were reduced in DMSXL even without flecainide injection (Table 2). Again the deep bradycardia and conduction blocks induced by flecainide in DMSXL 8-month-old mice rendered impossible tissue velocities Doppler analysis. These results indicated that the effects of flecainide on cardiac contractile properties were more pronounced in DMSXL than in WT mice.

Altogether, these observations support an enhanced sensitivity of DMSXL mice to the sodium channel blocker flecainide and suggest alterations of the sodium current $\left(I_{\mathrm{Na}}\right)$. As the cardiac alterations seemed to progress with age, only 8-month-old mice were used for tissue and cellular experiments in the rest of the study. 


\subsection{Abnormal gating properties of the sodium current in cardiomyocytes from DMSXL mice}

The study of $I_{\mathrm{Na}}$ was performed first in whole-cell patch-clamped ventricular myocytes. Representative families of $I_{\mathrm{Na}}$ obtained from WT and DMSXL myocytes are shown Figure 2A. Peak $I_{\mathrm{Na}}$ density, activation- $\mathrm{V}_{\mathrm{m}}$ and steady-state availability- $\mathrm{V}_{\mathrm{m}}$ relationships did not differ between WT and DMSXL mice (Figure 2B-C Table 3). The onset of inactivation was faster in DMSXL than in WT as evidenced by both the short time to reach half time of inactivation $\left(\mathrm{t}_{1 / 2}\right)$ (Figure 2D;Table 3 ) and the reduced time constant of inactivation $\left(\tau_{\text {fast }}\right.$, Figure $4 \mathrm{~A}$; Table 3$)$. Indeed $I_{N a}$ inactivated 1.7 times faster in DMSLX myocytes, at all tested membrane potentials (Figure 4A, B; Table 3).

To further characterize the cardiac electrical properties of the DMXL mouse, action potentials (AP) were recorded in strips of right ventricular free wall (Figure 3). The $[\mathrm{dV} / \mathrm{dt}]_{\max }$ of the upstroke phase was significantly decreased in DMSXL mice (Figure 3B; Table 3). The other main AP parameters (resting membrane potential and AP durations) did not differ between WT and DMSXL mice (Figure 3B; Table 3).

To evaluate the importance of the accelerated inactivation of $I_{\mathrm{Na}}$ in reducing the maximum upstroke velocity of the AP, we used a computer model of rat ventricular myocyte AP, the Oxsoft Heart Model v. 4.8. The consequence of the 1.7, $2.7(1.7+1$; mean + SD) and $0.7(1.7-1$; mean SD) times acceleration of the $I_{\mathrm{Na}}$ inactivation rate was thus assessed. Note that the 1.7 value was chosen according to the experimentally determined ratio of the fast time constant of $I_{\mathrm{Na}}$ inactivation $\left(\tau_{\text {fast }}\right)$ between WT and DMSXL (Figure 4A and B). As a consequence, the computed $[\mathrm{dV} / \mathrm{dt}]_{\max }$ lowered from $175 \mathrm{~V} / \mathrm{s}$ to $149 \mathrm{~V} / \mathrm{s}(-15 \%)$ for the 1.7 ratio and to $118 \mathrm{~V} / \mathrm{s}(-33 \%)$ for the 2.7 ratio of accelerated $I_{\mathrm{Na}}$ inactivation (Figure $4 \mathrm{C}, \mathrm{D}$ ). The 0.7 ratio increased the $[\mathrm{dV} / \mathrm{dt}]_{\max }$ from $175 \mathrm{~V} / \mathrm{s}$ to $203 \mathrm{~V} / \mathrm{s}(+16 \%)$.

Taken together, these results indicated that mild alterations of $I_{\mathrm{Na}}$ in DMSXL mice can effectively contribute to the reduced excitability as experimentally observed. 


\subsection{Molecular and tissue expression of $\mathrm{Na}_{\mathrm{v}} 1.5$ subunits in DMSXL and WT mice.}

We first studied the molecular characteristics of the SCN5A gene by performing DNA sequencing in 2 DMSXL and 2 WT mice and no mutation was detected. Next, we analyzed the expression of the $\mathrm{Na}_{\mathrm{v}} 1.5$ subunit using the indirect immunofluorescence approach. Figure 5A and 5B show that the distribution of $\mathrm{Na}_{\mathrm{v}} 1.5$ was similar in WT and DMSXL myocardium, the channel being expressed at the sarcolemma (at both the intercalated discs and lateral membranes) as well as at the costamere, facing the z-line. Of note, the ventricular myocytes from DMSXL mice appeared to be smaller than those from the WT mice, in agreement with the smaller membrane capacitance of cardiac myocytes from DMSXL mice $(122 \pm 33 \mathrm{pF}, \mathrm{n}=16)$ compared with the WT $(155 \pm 47 \mathrm{pF}$, $\mathrm{n}=22)$ mice $(P=0.02)$. Finally, picrosirius staining did not reveal significant fibrosis in either group of mice (Figure 5C).

\section{Discussion}

The present study is a detailed characterization of the cardiac phenotype of an original murine model of Steinert's disease that reproduces the chronic accumulation of CTG triplets in the heart. We provide evidence that discrete alterations in the properties of the sodium current contribute to the electrical and contractile cardiac dysfunction of this hereditary myopathy.

In DM1, direct access to heart tissue is limited to patients with end stage heart failure. Therefore, animal models are crucial for the understanding of the pathogenesis of this myopathy. Important information has been obtained already using murine models in which acute triplet expansion were induced. For instance, a few days after induction of triplet expansion in the heart, complete AV block and dilated cardiomyopathy are observed in a tamoxifen-induced CreloxP recombination mice model (Wang et al., 2007). In another murine model of inducible expression of the $D M P K$ gene that reproduces the DM1 muscle phenotype, complete AV block occurs eight days following induction of the triplet expansion and is reversible upon silencing of the triplet expansion 
(Mahadevan et al., 2006). These two studies indicate that conduction block could be the direct consequence of acute and massive triplet expansion in the heart and therefore suggest that distinct molecular mechanisms might be involved in this pathogenesis rather than an unspecific degenerative myocardial process.

The DMSXL mouse model of the present study constitutively expresses the human DM1 locus under the regulation of its own promoter and its cis regulatory elements resulting in a slow and steady-state expression of the triplet expansion as observed in DM1 patients. Thus, this is a precious model to study the time course of the disease with ageing. It has been previously shown that DMSXL mice have reduced muscle strength, lower motor performances, peripheral neuropathy and respiratory impairments (Huguet et al., 2012; Panaite et al., 2011; Panaite et al., 2013). However, we found no cardiac abnormality at the ECG and echocardiographic examination in baseline conditions in the DMSXL mouse. In clinical practice, sodium channel blockers are often used to reveal latent electrical conduction disturbances (Chiale et al., 1982; Wolpert et al., 2005). In DMSXL mice, the injection of the sodium channel blocker flecainide indeed unmasked cardiac abnormalities. In 8-month-old mice, the prolongation of ECG parameters (PR interval, QRS complexes) under flecainide was more pronounced in DMSXL than in WT mice and high degree AV block was documented in 6/9 DMSXL mice, an effect never observed in WT mice. This enhanced sensitivity to flecainide was not observed in 3-month-old mice (except for the lengthening of the QRS complexes), indicating a clear progression of the cardiac disease with ageing, as observed in DM1 patients. Taken together, our results and those obtained in a model of inducible CTG expansion (Mahadevan et al., 2006; Wang et al., 2007) indicate that the slow or rapid accumulation of CTG triplets in the heart could be responsible for the development of cardiac electrical abnormalities.

Flecainide injection reduced tissues velocities and strain rate in 3-month-old DMSXL mice. In 8-month-old DMSXL mice, these two tissue Doppler parameters were already reduced in 
baseline conditions, i.e. before flecainide injection. Firstly, these results are consistent with the progression with ageing of the cardiac disease with the accumulation of CTG triplets. Secondly, they suggest a link between electrical and contractile disturbances in DM1. For instance, it is possible that alterations of electrogenic system involved in the excitation-contraction coupling of cardiomyocytes such as the sodium current could account for both the electrical and conduction defects. Interestingly, such discrete alterations of cardiac contractile properties as evidenced by tissue velocities parameters has been previously described in patients with DM1(Di Cori et al., 2009; Lindqvist et al., 2010), but also in patients with channelopathies (long QT syndrome) and had been attributed to the dispersion of cardiac contraction (Haugaa et al., 2009). Both the sensitivity of these echocardiographic and electrocardiographic abnormalities to flecainide pointed to alterations in $I_{\mathrm{Na}}$.

Patch-clamp analysis showed mild abnormalities in $I_{\mathrm{Na}}$ in DMSXL. While the peak current density and its availability- $\mathrm{V}_{\mathrm{m}}$ relationship were similar between DMSXL and WT myocytes, the rate of $I_{\mathrm{Na}}$ inactivation was $1.7 \pm 1.0$ times increased in DMSXL mouse myocytes. This accelerated kinetic of current inactivation could reduce the amount of sodium entry during the phase 0 of the action potential. Indeed, microelectrode recording of ventricular action potential in ventricle strips confirmed the expected decrease of $[\mathrm{dV} / \mathrm{dt}]_{\max }$ in DMSXL. Moreover, the computer model of ventricular AP confirmed that the 1.7 times accelerated inactivation of $I_{\mathrm{Na}}$ could significantly contribute to lower the $[\mathrm{dV} / \mathrm{dt}]_{\max }$ by $15 \%$ on average. Interestingly, it has been shown that a $20 \%$ reduction of $[\mathrm{dV} / \mathrm{dt}]_{\max }$ could be responsible for a decrease in transverse conduction velocity and high degree AV block in patients harboring a G514C mutation on the SCN5A gene (Tan et al., 2001).

The mild $I_{\mathrm{Na}}$ alterations observed in DMSXL mice are similar to those reported for other electrical disorders associated with $I_{\mathrm{Na}}$ defects. For instance, the flecainide-induced bradycardia and conduction blocks in the 8-month-old DMSXL mice happened to be similar to those observed in 
mouse models of Brugada syndrome related to SCN5A mutations (Martin et al.; Remme et al., 2006). Moreover, accelerated kinetics of sodium current inactivation have been reported in SCN5A mutations with complex $I_{\mathrm{Na}}$ alterations and Brugada syndrome (Dumaine et al., 1999; Mohler et al., 2004). A recent study reports a high incidence of typical ECG traces of Brugada syndrome associated with conduction disorders in 7/914 DM1 patients (Wahbi et al., in press). Altogether, these studies suggest shared electrical mechanisms between DM1 and Brugada syndrome. In the same line, the reduction of $[\mathrm{dV} / \mathrm{dt}]_{\max }$ caused by $S C N 5 A$ mutations can cause either high degree AV block or Brugada syndrome (due to the gradient of repolarisation between the endocardium and the epicardium) (Tan et al., 2001).

Sodium current dysfunction has been previously associated with heterogeneous phenotypes characterized by variable manifestation (Brugada syndrome, Familial Progressive Cardiac Conduction System Disease or even dilated cardiomyopathy) (McNair et al., 2004; Schott et al., 1999). A single SCN5A mutation may induce either a single phenotype, or several distinct phenotypes (Kyndt et al., 2001). Here, we provide new evidence that alterations in the sodium current could contribute to both cardiac electrical and mechanical disturbances in an original mouse model of DM1. DM1 myopathy could be another example of a complex disease associated with mild modification of the sodium current. Further studies aiming to identify the molecular mechanisms underlying $I_{\mathrm{Na}}$ dysfunction in DM1 are now warranted. 


\section{Materials and methods}

\subsection{DMSXL transgenic mouse model of DM1}

The 45-kb genomic fragment carrying the dystrophia myotonica protein kinase gene from a DM1 locus patient was used to create the DMSXL transgenic mouse model with $>1000$ cytosinethymine-guanine repeats expansion (Seznec et al., 2000). DMSXL mice show the highest level of expression of CTG repeats and nuclear DMPK mRNA foci in cardiac and skeletal muscles (GomesPereira et al., 2007; Huguet et al., 2012; Seznec et al., 2000). Housing and handling of mice were performed in accordance with the guidelines established by the French Council on animal care "Guide for the Care and Use of Laboratory Animals": EEC86/609 Council Directive - Decree 2001-131.

\subsection{Electrocardiographic measurements}

We anesthetized 3- and 8-month-old WT and DMSXL mice with an intraperitoneal injection (i.p.) of pentobarbital (20mg/kg ip). The surface ECG was recorded using 23-gauge, subcutaneous Gould RS 3200 needle electrodes (Gould Instrument Systems), affixed to each limb. ECG was continuously monitored for $5 \mathrm{~min}$ before (baseline) and $16 \mathrm{~min}$ after the injection of the antiarrhythmic drug flecainide acetate, $20 \mathrm{mg} / \mathrm{kg}$ body weight, i.p. Indeed, class I antiarrhythmic drugs are used as a pharmacological stress testing of conduction disorders in humans (Enclund et al., 1998) . Moreover, flecainide test has been used in transgenic mice with mutated cardiac sodium channel to reveal concealed conduction disorders (Martin et al.; Remme et al., 2006). Heart rate and PQ, QRS, and QT duration were measured manually. The values obtained from 5 consecutive cardiac cycles were averaged. The QT interval was corrected for heart rate, using the modified Bazett formula, QTc $=\mathrm{QT} /(\mathrm{RR} / 100)^{0.5}$.

\subsection{Conventional and Tissue Doppler imaging echocardiography}


Echocardiographic images were acquired in 3-month-old and 8-month-old WT and DMSXL mice, using a 13-MHz linear-array transducer with a digital ultrasound system (Vivid 7, GE Medical Systems). Mice were lightly sedated with an i.p. of ketamine $80 \mathrm{mg} / \mathrm{kg}$. Acquisitions were carried out before and $16 \mathrm{~min}$ after the injection of flecainide acetate, $20 \mathrm{mg} / \mathrm{kg}$ body weight, i.p.

Standard echocardiography included the measurements of left ventricular (LV) end diastolic diameter, interventricular septal thickness, LV ejection fraction and mitral E wave. Tissue Doppler images were collected with the use of parasternal short-axis views at the midventricular level, at a frame rate of 483 frames per second and a depth of $1 \mathrm{~cm}$. The Nyquist limit of the velocity was 15 $\mathrm{cm} / \mathrm{s}$, with a pulse repetition frequency of $2.5 \mathrm{kHz}$. TDI analysis was performed offline with the use of a customized version of the EchoPac Software (GE Medical). Myocardial velocities were computed from a region of interest $(0.2 \times 0.2 \mathrm{~mm})$ that was manually positioned along the posterior wall on the endocardial and epicardial surfaces to measure the peak systolic endo $\left(\mathrm{V}_{\text {endo }}\right)$ and epicardial ( $\left.\mathrm{V}_{\text {epi }}\right)$ velocities, respectively, as previously described (Sebag et al., 2005). Radial strain rate (SR) was then measured over an axial distance of $1 \mathrm{~mm}$ (width $0.6 \mathrm{~mm}$ ). A tissue Doppler frequency of $6.4 \mathrm{MHz}$ was used. The temporal smoothing filters were turned off for all measurements. Time-velocity and time-SR plots were obtained, and peak systolic velocities and SR were measured. The values obtained in 5 consecutive cardiac cycles were averaged. The echocardiographic data were compared only if the heart rates did not differ amongst the two groups.

\subsection{Patch-clamp experiments}

Ventricular myocytes were isolated by the Langendorff perfusion technique as previously described (Leroy et al., 2011). Sodium current $\left(I_{\mathrm{Na}}\right)$ was recorded by the whole-cell patch-clamp technique in freshly isolated cardiomyocytes from 8-month-old WT and DMSXL mice at a room temperature of $22-25^{\circ}$ C. Sodium current density-membrane potential $\left(V_{m}\right)$ relationships were calculated and 
peaks of the current were compared at $-20 \mathrm{mV}$. The activation- $\mathrm{V}_{\mathrm{m}}$ and availability- $\mathrm{V}_{\mathrm{m}}$ relationships were also determined. Ionic currents were recorded by the whole-cell patch-clamp technique with an Axopatch $^{\mathrm{TM}}$ 200B patch-clamp amplifier (Axon Instruments, Molecular Devices). The resistance of the Corning ${ }^{\circledR}$ Kovar Sealing code 7052, WPI patch pipettes (Glass Dynamics) ranged between 1 and $2 \mathrm{M} \Omega$. The currents were filtered at $20 \mathrm{kHz}(-3 \mathrm{~dB}, 8$-pole low-pass Bessel filter) and digitized at $50 \mathrm{kHz}$ using a Digidata 1200 acquisition system (Axon Instruments). The cell membrane capacitance was determined according to Momtaz et al. (Momtaz et al., 1996). The series resistance was compensated at 80 to $95 \%$, resulting in $<3 \mathrm{mV}$ errors; the cell membrane capacitive current and the leakage current were compensated. The peak $I_{\mathrm{Na}}$ amplitude was monitored according to a steady-state pulse protocol: a 300 milliseconds depolarizing test pulse to $-30 \mathrm{mV}$ from a $\mathrm{HP}$ of $-100 \mathrm{mV}$ at $0.2 \mathrm{~Hz}$. An equilibration period was allowed until the peak $I_{\mathrm{Na}}$ amplitude reached the steady-state.

The steady-state pulse protocol was applied before activation- $\mathrm{V}_{\mathrm{m}}$ and availability- $\mathrm{V}_{\mathrm{m}}$. For the activation- $\mathrm{V}_{\mathrm{m}}$ protocol, the currents were elicited by 100 milliseconds depolarizing pulses applied at $0.2 \mathrm{~Hz}$ from $\mathrm{HP}-120 \mathrm{mV}$, in $5-$ or $10-\mathrm{mV}$ increments, between -100 and $+50 \mathrm{mV}$. The steadystate availability- $\mathrm{V}_{\mathrm{m}}$ protocol was from a $\mathrm{HP}$ of $-100 \mathrm{mV}$; a 1-sec conditioning pre-pulse was applied in 5- or 10-mV increments, between -140 and $-30 \mathrm{mV}$, followed by a 100 milliseconds test pulse to $0 \mathrm{mV}$ at $0.2 \mathrm{~Hz}$. Data for activation- $\mathrm{V}_{\mathrm{m}}$ and steady-state availability- $\mathrm{V}_{\mathrm{m}}$ relationships of $I_{\mathrm{Na}}$ were fitted to the Boltzmann distribution equation: $\mathrm{Y}=1 /\left\{1+\exp \left[-\left(\mathrm{V}_{\mathrm{m}}-\mathrm{V}_{0.5}\right) / \mathrm{k}\right]\right\}$, where $\mathrm{V}_{\mathrm{m}}$ is the membrane potential, $\mathrm{V}_{0.5}$ is the half-activation or half-availability potential. For activation- $\mathrm{V}_{\mathrm{m}}$ curves, $\mathrm{Y}$ represents the relative conductance. For availability- $\mathrm{V}_{\mathrm{m}}$ curves, $\mathrm{Y}$ represents the relative current. Fast onset of inactivation was evaluated i) by measuring the time to half decay of inactivation of the peak current for each membrane potential $\left(\mathrm{V}_{\mathrm{m}}\right)$ ranging from -55 to $0 \mathrm{mV}$, as previously described (Mohler et al., 2004) and ii) by calculating the fast time constant $\left(\tau_{\text {fast }}\right)$. The $I_{\mathrm{Na}}$ inactivation was fitted with a double exponential curve using the Sigmaplot 11.0 software 
(Systat Software Inc.). For the recordings of whole-cell current, the intracellular pipette solution contained (in mmol/L): $\mathrm{NaCl} 5, \mathrm{CsCl} 130, \mathrm{MgCl}_{2} 2, \mathrm{CaCl}_{2}$ 2, EGTA 15, HEPES 10, and MgATP 4, pH 7.2 with $\mathrm{CsOH}$. The external solution contained: $\mathrm{NaCl} 25, \mathrm{CsCl} 108.5, \mathrm{CaCl}_{2}$ 0.5, $\mathrm{MgCl}_{2}$ 2, 4AP 5, $\mathrm{CoCl}_{2}$ 5, HEPES 10, and glucose 10, $\mathrm{pH} 7.4$ with $\mathrm{CsOH}$. The myocytes were bathed in Tyrode solution containing: $\mathrm{NaCl} 135, \mathrm{KCl} 4, \mathrm{MgCl}_{2} 2, \mathrm{CaCl}_{2}$ 1.8, HEPES 10, $\mathrm{NaH}_{2} \mathrm{PO}_{4}$ 1, Napyruvate 2.5 and glucose $20, \mathrm{pH} 7.4$ with $\mathrm{NaOH}$. The chemicals were purchased from SigmaAldrich Chimie.

\subsection{Action potential recordings}

Action potentials (AP) were recorded using the standard microelectrode technique (Coraboeuf et al., 1979) on strips of the right ventricle of 8-month-old WT and DMSXL mice. The preparations were stimulated (Isostim A320, World Precision Instruments Inc.) via a bipolar Ag-electrode with 1-ms pulses at twice the threshold voltage. AP were recorded using 15-30 M $\Omega$ standard glass microelectrodes filled with $3 \mathrm{~mol} / \mathrm{L} \mathrm{KCl}$ and coupled to a high-input impedance preamplifier (Intracellular Electrometer IE-210, Warner Instrument Corp). The AP were displayed on an oscilloscope and simultaneously digitized and analyzed with the interactive Acquis1 software, version 4.0 (Gerard Sadoc, CNRS, Gif/Yvette, France). The preparations were stimulated at $1 \mathrm{~Hz}$ and allowed to equilibrate for $\geq 1 \mathrm{~h}$, before the onset of recording. The AP measurements included maximum upstroke velocity $\left([\mathrm{dV} / \mathrm{dt}]_{\max }\right)$, resting membrane $\left(\mathrm{E}_{\mathrm{r}}\right)$ potential and duration at 25,50 and $90 \%\left(\mathrm{APD}_{25,50,90}\right)$ of repolarization.

\subsection{Computer simulations of membrane action potential}

Computer simulations of membrane action potential were achieved using Oxsoft Heart Model v. 4.8 (written by and available from Pr. D. Noble, Oxford University; copyright by OXFORD Ltd, UK) (DiFrancesco and Noble, 1985). This mathematical modeling software solves the equations 
developed to model currents associated with ion channels, exchangers and pumps in the heart, and then reconstitute the cellular action potential. We selected it because of its easy commercial availability and because it contains all the parameters needed to verify the importance of the changes in the speed of $I_{\mathrm{Na}}$ inactivation on the $[\mathrm{dV} / \mathrm{dt}]_{\max }$ of the AP upstroke. We used the built-in model of rat ventricular AP. Resting membrane potentials $\left(\mathrm{E}_{\mathrm{r}}\right)$ were adjusted according to experimental recordings by simply altering the appropriate input $[\mathrm{K}]_{\mathrm{o}}$ and $[\mathrm{K}]_{\mathrm{i}}$ as allowed by the model entries. The $I_{\mathrm{Na}}$ inactivation rate was modified, following the ratio of the $\tau_{\text {fast }}$ between WT and DMSXL currents and the resulting effect on $[\mathrm{dV} / \mathrm{dt}]_{\max }$ was retrieved.

\subsection{Tissue analysis of ventricular myocardium}

Frozen, $10 \mu \mathrm{m}$ - thick slices of ventricles harvested from 8-month-old WT and DMSXL mice were stained with picrosirius red to measure the amount of cardiac fibrosis. For indirect immunofluorescence, slices were permeabilized with acetone for $10 \mathrm{~min}$, before incubation for $1 \mathrm{~h}$ at room temperature in phosphate buffered saline containing $1 \%$ bovine serum albumin and $10 \%$ normal goat serum as a blocking buffer. The slices were incubated with the primary rabbit anti$\mathrm{Na}_{\mathrm{v}} 1.5$ antibody (Alomone labs) diluted 1:50 in blocking buffer (phosphate buffered saline with 1\% bovine serum albumin, $3 \%$ normal goat serum) for $2 \mathrm{~h}$, at room temperature. The primary antibody was detected by incubating slices with the secondary Alexa Fluor ${ }^{\circledR} 594$ goat anti-rabbit antibody (Molecular Probes ${ }^{\circledR}$; Life Technologies Corporation) diluted 1:400, and with the nuclear dye 4',6diamidino-2-phenylindole (Sigma-Aldrich) diluted 1:500 in the same blocking buffer for $1 \mathrm{~h}$. Images were acquired with a cooled CoolSnap ${ }^{\mathrm{TM}}$ camera (Roper-Scientific) mounted on an Olympus epifluorescent microscope with x10 and x20 objectives for classical epifluoresence analysis. High resolution 3-dimensionnal microscopy was also performed using a 60X (UPlanSApo, 0.17) objective. For each sample, a series of consecutive planes (stack of images) were acquired (sectioning step, $0.2 \mu \mathrm{m}$ ) and deconvoluted using acquired PSF. Images were 
processed and analyzed using Metamorph software (Molecular Devices) supplemented with the 3D-deconvolution module. For each sample, 3 consecutive z-images were thresholded to similar levels and z-projections were carried on using the ImageJ software.

\subsection{Genetic studies}

Total cardiac RNA was extracted using the Chomczynski procedure through the kit RNAPLUS2 ${ }^{\mathrm{TM}}$.The total RNA was reverse-transcripted into cDNA and a set of primers spanning the SCN5A cDNA was selected. Polymerase Chain Reaction (PCR) was performed in GeneAmp* PCR System 9700 (Applied biosystems) and products were analyzed by Gel Electrophoresis and were sequenced using "BigDye Terminator v.3.1 cycle sequencing kit", on ABI PRISM 3130 analyser (Applied Biosystems).

\subsection{Statistical analysis}

The data are expressed as means \pm standard deviation for continuous variables or median $(25 \%$ and $75 \%$ interquartiles) as requested. Categorical variables are expressed as counts and percentages. Continuous variables were compared using t-test or Mann-Whitney's U test as requested. Categorical variables were compared using Chi-square test or Fisher's exact test as requested. For multiple comparisons, a two way ANOVA for repeated measures was performed and post-hoc analysis was done using the Bonferroni test. A $P$ value $<0.05$ was considered significant. The Sigmaplot $^{\circledR}$ statistical software, version 11.0 was used for all analyses. 


\section{Acknowledgements:}

The authors thank Florent Louault and Dr. Nathalie Mougenot for their expert assistance in the cardiac immunohistochemical studies.

Competing interests' statement: none to declare.

\section{Author contributions:}

VA, KW, CB, RF, BE, DD and SH conceived and designed the experiments.

VA, KW, FS and KA performed the experiments.

VA, KW, FS, CB, EB and AC analyzed the data.

GG contributed materials transgenic mice.

VA, KW, EB, AC, DD and SH wrote the paper.

\section{Funding:}

This study was funded by grants from the Association Française contre les Myopathies (French Alliance against Myopathies), from the Fédération Française de Cardiologie (French Cardiology Federation), from the Leducq Foundation: "Structural Alterations in the Myocardium and the Substrate for Cardiac Fibrillation" And from the "Agence Nationale pour la Recherche" (ANR). 


\section{References:}

Amack, J. D., Paguio, A. P. and Mahadevan, M. S. (1999). Cis and trans effects of the myotonic dystrophy (DM) mutation in a cell culture model. Hum Mol Genet 8, 1975-84.

Ashizawa, T. and Epstein, H. F. (1991). Ethnic distribution of myotonic dystrophy gene. Lancet 338, 642-3.

Chiale, P. A., Przybylski, J., Laiño, R. A., Halpern, M. S., Nau, G. J., Sánchez, R. A., Lázzari, J. O., Elizari, M. V. and Rosenbaum, M. B. (1982). Usefulness of the ajmaline test in patients with latent bundle branch block. Am. J. Cardiol. 49, 21-26.

Coraboeuf, E., Deroubaix, E. and Coulombe, A. (1979). Effect of tetrodotoxin on action potentials of the conducting system in the dog heart. Am. J. Physiol. 236, H561-567.

De Die-Smulders, C. E., Howeler, C. J., Thijs, C., Mirandolle, J. F., Anten, H. B., Smeets, H. J., Chandler, K. E. and Geraedts, J. P. (1998). Age and causes of death in adult-onset myotonic dystrophy. Brain 121 ( Pt 8), 1557-63.

Di Cori, A., Bongiorni, M. G., Zucchelli, G., Soldati, E., Falorni, M., Segreti, L., Gemignani, C., Siciliano, A., Bovenzi, F. M. and Di Bello, V. (2009). Early left ventricular structural myocardial alterations and their relationship with functional and electrical properties of the heart in myotonic dystrophy type 1. J Am Soc Echocardiogr 22, 1173-1179.

DiFrancesco, D. and Noble, D. (1985). A model of cardiac electrical activity incorporating ionic pumps and concentration changes. Philos. Trans. R. Soc. Lond., B, Biol. Sci. 307, 353-398.

Dumaine, R., Towbin, J. A., Brugada, P., Vatta, M., Nesterenko, D. V., Nesterenko, V. V., Brugada, J., Brugada, R. and Antzelevitch, C. (1999). Ionic mechanisms responsible for the electrocardiographic phenotype of the Brugada syndrome are temperature dependent. Circ Res 85, 803-9.

Enclund, A., Bergfeldt, L. and Rosenqvist, M. (1998). Pharmacological Stress Testing of the His-Purkinje System in Patients with Bifascicular Block. Pacing and Clinical Electrophysiology 21, 1979-1987.

Gomes-Pereira, M., Foiry, L., Nicole, A., Huguet, A., Junien, C., Munnich, A. and Gourdon, G. (2007). CTG trinucleotide repeat "big jumps": large expansions, small mice. PLoS Genet 3, e52.

Groh, W. J., Groh, M. R., Saha, C., Kincaid, J. C., Simmons, Z., Ciafaloni, E., Pourmand, R., Otten, R. F., Bhakta, D., Nair, G. V., et al. (2008). Electrocardiographic abnormalities and sudden death in myotonic dystrophy type 1. N Engl J Med 358, 2688-97.

Haugaa, K. H., Edvardsen, T., Leren, T. P., Gran, J. M., Smiseth, O. A. and Amlie, J. P. (2009). Left ventricular mechanical dispersion by tissue Doppler imaging: a novel approach for identifying high-risk individuals with long QT syndrome. Eur. Heart J. 30, 330-337.

Huguet, A., Medja, F., Nicole, A., Vignaud, A., Guiraud-Dogan, C., Ferry, A., Decostre, V., Hogrel, J.-Y., Metzger, F., Hoeflich, A., et al. (2012). Molecular, physiological, and 
motor performance defects in DMSXL mice carrying >1,000 CTG repeats from the human DM1 locus. PLoS Genet. 8, e1003043.

Koshizuka, R., Ishizu, T., Kameda, Y., Kawamura, R., Seo, Y. and Aonuma, K. (2013). Longitudinal strain impairment as a marker of the progression of heart failure with preserved ejection fraction in a rat model. J Am Soc Echocardiogr 26, 316-323.

Kyndt, F., Probst, V., Potet, F., Demolombe, S., Chevallier, J. C., Baro, I., Moisan, J. P., Boisseau, P., Schott, J. J., Escande, D., et al. (2001). Novel SCN5A mutation leading either to isolated cardiac conduction defect or Brugada syndrome in a large French family. Circulation 104, 3081-6.

Leroy, J., Richter, W., Mika, D., Castro, L. R. V., Abi-Gerges, A., Xie, M., Scheitrum, C., Lefebvre, F., Schittl, J., Mateo, P., et al. (2011). Phosphodiesterase 4B in the cardiac Ltype $\mathrm{Ca}^{2+}$ channel complex regulates $\mathrm{Ca}^{2+}$ current and protects against ventricular arrhythmias in mice. J. Clin. Invest. 121, 2651-2661.

Lindqvist, P., Mörner, S., Olofsson, B. O., Backman, C., Lundblad, D., Forsberg, H. and Henein, M. Y. (2010). Ventricular dysfunction in type 1 myotonic dystrophy: electrical, mechanical, or both? Int. J. Cardiol. 143, 378-384.

Mahadevan, M., Tsilfidis, C., Sabourin, L., Shutler, G., Amemiya, C., Jansen, G., Neville, C., Narang, M., Barcelo, J., O'Hoy, K., et al. (1992). Myotonic Dystrophy Mutation: An Unstable CTG Repeat in the 3' Untranslated Region of the Gene. Science 255, 1253-1255.

Mahadevan, M. S., Yadava, R. S., Yu, Q., Balijepalli, S., Frenzel-McCardell, C. D., Bourne, T. D. and Phillips, L. H. (2006). Reversible model of RNA toxicity and cardiac conduction defects in myotonic dystrophy. Nat. Genet. 38, 1066-1070.

Mankodi, A., Logigian, E., Callahan, L., McClain, C., White, R., Henderson, D., Krym, M. and Thornton, C. A. (2000). Myotonic dystrophy in transgenic mice expressing an expanded CUG repeat. Science 289, 1769-73.

Martin, C. A., Zhang, Y., Grace, A. A. and Huang, C. L. In vivo studies of Scn5a+/- mice modeling Brugada syndrome demonstrate both conduction and repolarization abnormalities. J Electrocardiol 43, 433-9.

Mathieu, J., Allard, P., Potvin, L., Prevost, C. and Begin, P. (1999). A 10-year study of mortality in a cohort of patients with myotonic dystrophy. Neurology 52, 1658-62.

McNair, W. P., Ku, L., Taylor, M. R., Fain, P. R., Dao, D., Wolfel, E. and Mestroni, L. (2004). SCN5A mutation associated with dilated cardiomyopathy, conduction disorder, and arrhythmia. Circulation 110, 2163-7.

Mohler, P. J., Rivolta, I., Napolitano, C., LeMaillet, G., Lambert, S., Priori, S. G. and Bennett, V. (2004). Nav1.5 E1053K mutation causing Brugada syndrome blocks binding to ankyrin-G and expression of Nav1.5 on the surface of cardiomyocytes. Proc Natl Acad Sci U S A 101, 17533-8.

Momtaz, A., Coulombe, A., Richer, P., Mercadier, J. J. and Coraboeuf, E. (1996). Action potential and plateau ionic currents in moderately and severely DOCA-salt hypertrophied rat hearts. J Mol Cell Cardiol 28, 2511-22. 
Panaite, P.-A., Kielar, M., Kraftsik, R., Gourdon, G., Kuntzer, T. and Barakat-Walter, I. (2011). Peripheral neuropathy is linked to a severe form of myotonic dystrophy in transgenic mice. J. Neuropathol. Exp. Neurol. 70, 678-685.

Panaite, P.-A., Kuntzer, T., Gourdon, G., Lobrinus, J. A. and Barakat-Walter, I. (2013). Functional and histopathological identification of the respiratory failure in a DMSXL transgenic mouse model of myotonic dystrophy. Dis Model Mech.

Remme, C. A., Verkerk, A. O., Nuyens, D., van Ginneken, A. C., van Brunschot, S., Belterman, C. N., Wilders, R., van Roon, M. A., Tan, H. L., Wilde, A. A., et al. (2006). Overlap syndrome of cardiac sodium channel disease in mice carrying the equivalent mutation of human SCN5A-1795insD. Circulation 114, 2584-94.

Schott, J. J., Alshinawi, C., Kyndt, F., Probst, V., Hoorntje, T. M., Hulsbeek, M., Wilde, A. A., Escande, D., Mannens, M. M. and Le Marec, H. (1999). Cardiac conduction defects associate with mutations in SCN5A. Nat Genet 23, 20-1.

Sebag, I. A., Handschumacher, M. D., Ichinose, F., Morgan, J. G., Hataishi, R., Rodrigues, A. C. T., Guerrero, J. L., Steudel, W., Raher, M. J., Halpern, E. F., et al. (2005). Quantitative assessment of regional myocardial function in mice by tissue Doppler imaging: comparison with hemodynamics and sonomicrometry. Circulation 111, 2611-2616.

Seznec, H., Lia-Baldini, A. S., Duros, C., Fouquet, C., Lacroix, C., Hofmann-Radvanyi, H., Junien, C. and Gourdon, G. (2000). Transgenic mice carrying large human genomic sequences with expanded CTG repeat mimic closely the DM CTG repeat intergenerational and somatic instability. Hum Mol Genet 9, 1185-94.

Tan, H. L., Bink-Boelkens, M. T., Bezzina, C. R., Viswanathan, P. C., Beaufort-Krol, G. C., van Tintelen, P. J., van den Berg, M. P., Wilde, A. A. and Balser, J. R. (2001). A sodium-channel mutation causes isolated cardiac conduction disease. Nature 409, 10431047.

Wahbi, K., Ederhy, S., Becane, H. M., Meune, C., Behin, A., Stojkovic, T., Laforet, P., Eymard, B., Duboc, D. and Cohen, A. (2012a). Impaired myocardial deformation detected by speckle-tracking echocardiography in patients with myotonic dystrophy type 1 . Int $J$ Cardiol 152, 375-6.

Wahbi, K., Meune, C., Porcher, R., Bécane, H. M., Lazarus, A., Laforêt, P., Stojkovic, T., Béhin, A., Radvanyi-Hoffmann, H., Eymard, B., et al. (2012b). Electrophysiological study with prophylactic pacing and survival in adults with myotonic dystrophy and conduction system disease. JAMA 307, 1292-1301.

Wang, G. S., Kearney, D. L., De Biasi, M., Taffet, G. and Cooper, T. A. (2007). Elevation of RNA-binding protein CUGBP1 is an early event in an inducible heart-specific mouse model of myotonic dystrophy. J Clin Invest 117, 2802-11.

Wolpert, C., Echternach, C., Veltmann, C., Antzelevitch, C., Thomas, G. P., Spehl, S., Streitner, F., Kuschyk, J., Schimpf, R., Haase, K. K., et al. (2005). Intravenous drug challenge using flecainide and ajmaline in patients with Brugada syndrome. Heart Rhythm 2, 254-260. 


\section{Figure legends:}

Figure 1: Cardiac electrocardiogram and echography.

(A): Cardiac ECG recordings in 8 months wild type (WT) versus transgenic DMSXL mice, before and after the injection of flecainide. Representative digital ECG traces before (left) and 16 minutes after (right) the intraperitoneal injection of $20 \mathrm{mg} / \mathrm{kg}$ flecainide. Top traces: WT mouse; the PR interval increased and QRS complex widened after the injection of flecainide. Bottom traces: DMSXL mouse; complete AV dissociation $\left(3^{\text {rd }}\right.$ degree AV block) developed after the injection of flecainide. P: P waves; QRS: QRS complexes; ms: milliseconds.

(B): Cardiac echography and tissue Doppler imaging. Tissue Doppler imaging was performed on parasternal short axis echocardiographic view at midventricular level in mouse (left scheme). The region of interest was manually positioned along the posterior wall within the endocardium and epicardium to measure the endocardial and epicardial velocities (respectively yellow trace and blue trace). Velocities were measured on the peak of the $\mathrm{S}$ wave (* on the Figure).

Figure 2: Comparison of kinetic and biophysical characteristics of sodium currents recorded from ventricular myocytes isolated from WT and DMSXL mice. (A): Sample family traces of $I_{\mathrm{Na}}$ from WT and DMSXL mice. For the sake of comparison, the current amplitudes were normalized. (B): Current density-voltage $\left(\mathrm{V}_{\mathrm{m}}\right)$ relationships of peak $I_{\mathrm{Na}} \cdot(\mathbf{C})$ : Average steady-state availability- $V_{m}$ (relative current) and activation- $V_{m}$ (relative conductance) relationships. Raw data curves were fitted, using of the Boltzmann distribution equation. All fit-determined parameters are reported in Table 3. (D): Kinetics of $I_{\mathrm{Na}}$ inactivation were determined by measuring the time to half inactivation $\left(\mathrm{t}_{1 / 2}\right)$ - membrane potential $\left(\mathrm{V}_{\mathrm{m}}\right)$. The duration from maximal peak amplitude to $50 \%$ of current inactivation defined $\mathrm{t}_{1 / 2} .{ }^{*} P<0.05$; WT, $\mathrm{n}=16$; DMSXL, $\mathrm{n}=24$; ms: milliseconds. 


\section{Figure 3: Comparison of Action potential (AP) recordings from WT and DMSXL mice.}

APs were recorded by the microelectrode technique in strips of right ventricular free wall. (A): Typical sample traces of AP from WT and DMSXL mice. (B): Bar graphs summarizing AP parameters (from the left to the right: resting potential, $[\mathrm{dV} / \mathrm{dt}]_{\max }$, AP durations at $25 \%, 50 \%$ and $90 \%$ of the repolarization). Of note, the DMSXL mouse exhibited a significant smaller $[\mathrm{dV} / \mathrm{dt}]_{\max }$ than WT mice, indicating a reduced $I_{\mathrm{Na}}$ contribution. Extensive data analysis is provided in Table 3 . $* P<0.05$.

\section{Figure 4: Computer simulations of ventricular membrane action potential.}

(A): The fast time constant of inactivation $\left(\tau_{\text {fast }}\right)$ of $I_{\mathrm{Na}}$ was smaller in DMSXL myocytes compared to WT. (B): Calculated ratio $\left(\tau_{\mathrm{WT}} / \tau_{\mathrm{DMSXL}}\right)$ for the indicated tested membrane potentials showing a $1.7 \pm 1.0$ times acceleration of the inactivation in DMSXL mice. $(\mathbf{C})$ : Model action potentials obtained by applying the control $I_{\mathrm{Na}}$ rate of inactivation (x1) and by successively applying increasing rates of inactivation (x1.7 and x2.7). (D): Corresponding computed $\mathrm{dV} / \mathrm{dt}$ as function of time showing the decrease in $[\mathrm{dV} / \mathrm{dt}]_{\max }$ when the rate of inactivation is increased (control $\mathbf{x 1}: 175$ $\mathrm{V} / \mathrm{s} ; \mathbf{1 . 7 x}: 149 \mathrm{~V} / \mathrm{s} ; \mathbf{2 . 7 x}: 118 \mathrm{~V} / \mathrm{s})$. ms: milliseconds.

\section{Figure 5: Tissue analysis of ventricular myocardium of WT and DMSXL mice.}

Immunohistochemistry showing the distribution of $\mathrm{Na}_{\mathrm{v}} 1.5$ channel in left ventricle using (A) classical epifluorescence microscopy and (B) high resolution 3-dimensionnal microscopy from WT (left panel) and DMSXL (right panel) mice. Arrow heads indicate the intercalated discs. In general overview, as well as in magnification panels, no obvious change was noted in the localization of $\mathrm{Na}_{\mathrm{v}} 1.5$ in the DMSXL mice compared to WT. It is noteworthy that the DMSXL mice cardiomyocytes are of smaller size. (C): Histochemichal analysis of fibrosis shown by picrosirius red staining in frozen sections of left ventricle. Fibrosis appeared in red and healthy tissue in 
yellow. No significant fibrosis was observed either in the WT mice (left panel) or in the DMSXL (right panel). 


\section{FIGURES}

Figure 1:

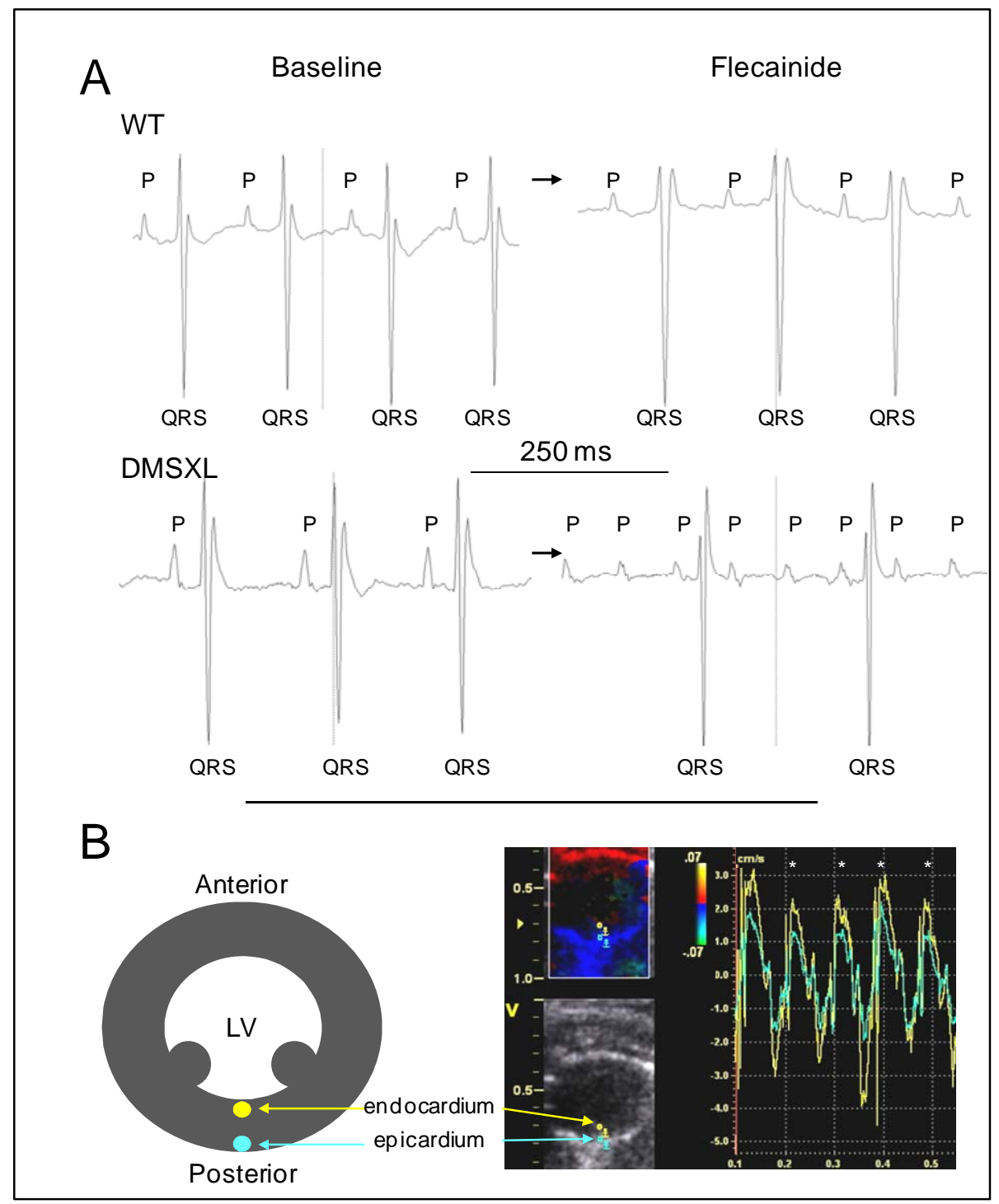




\section{Figure 2:}

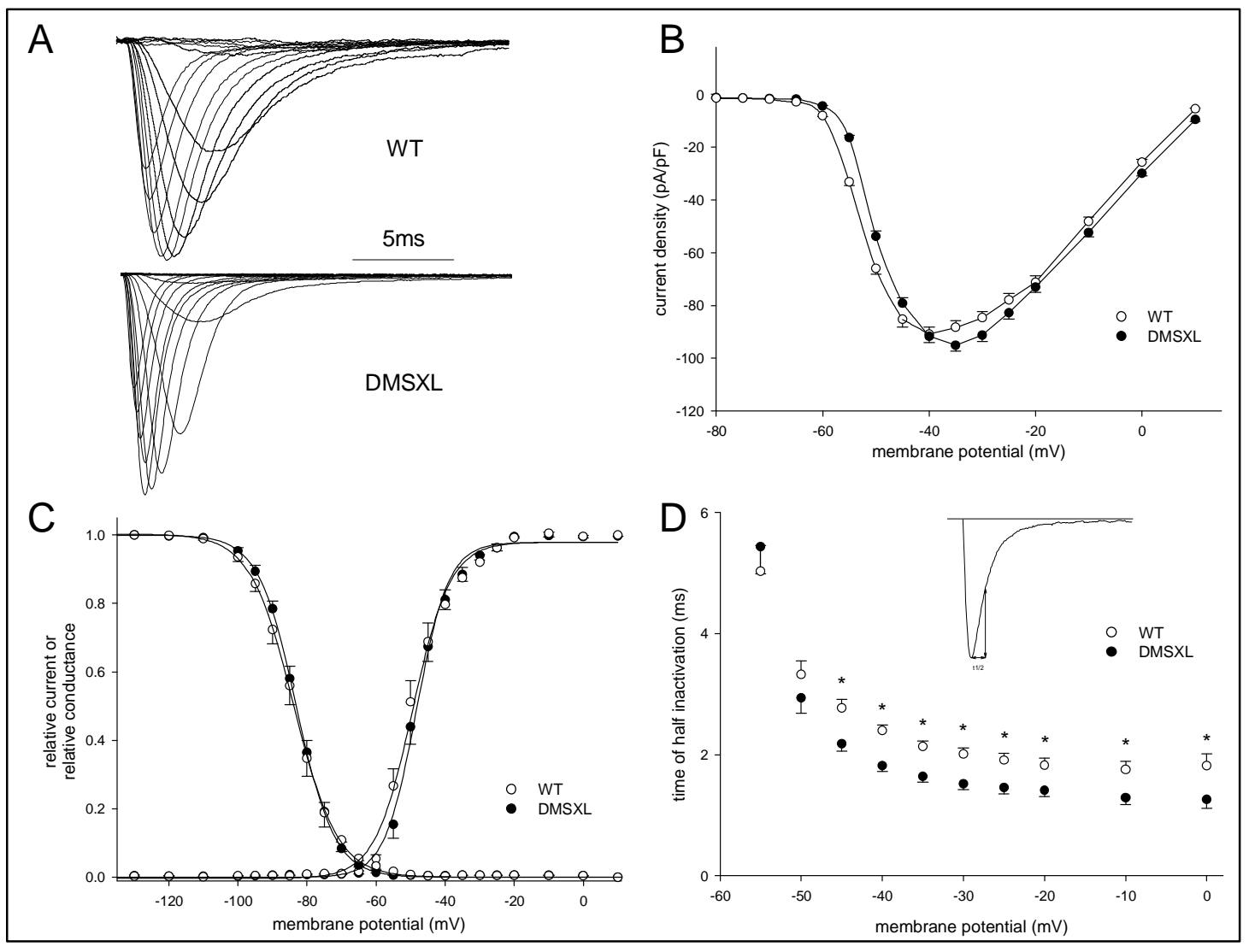


Figure 3:

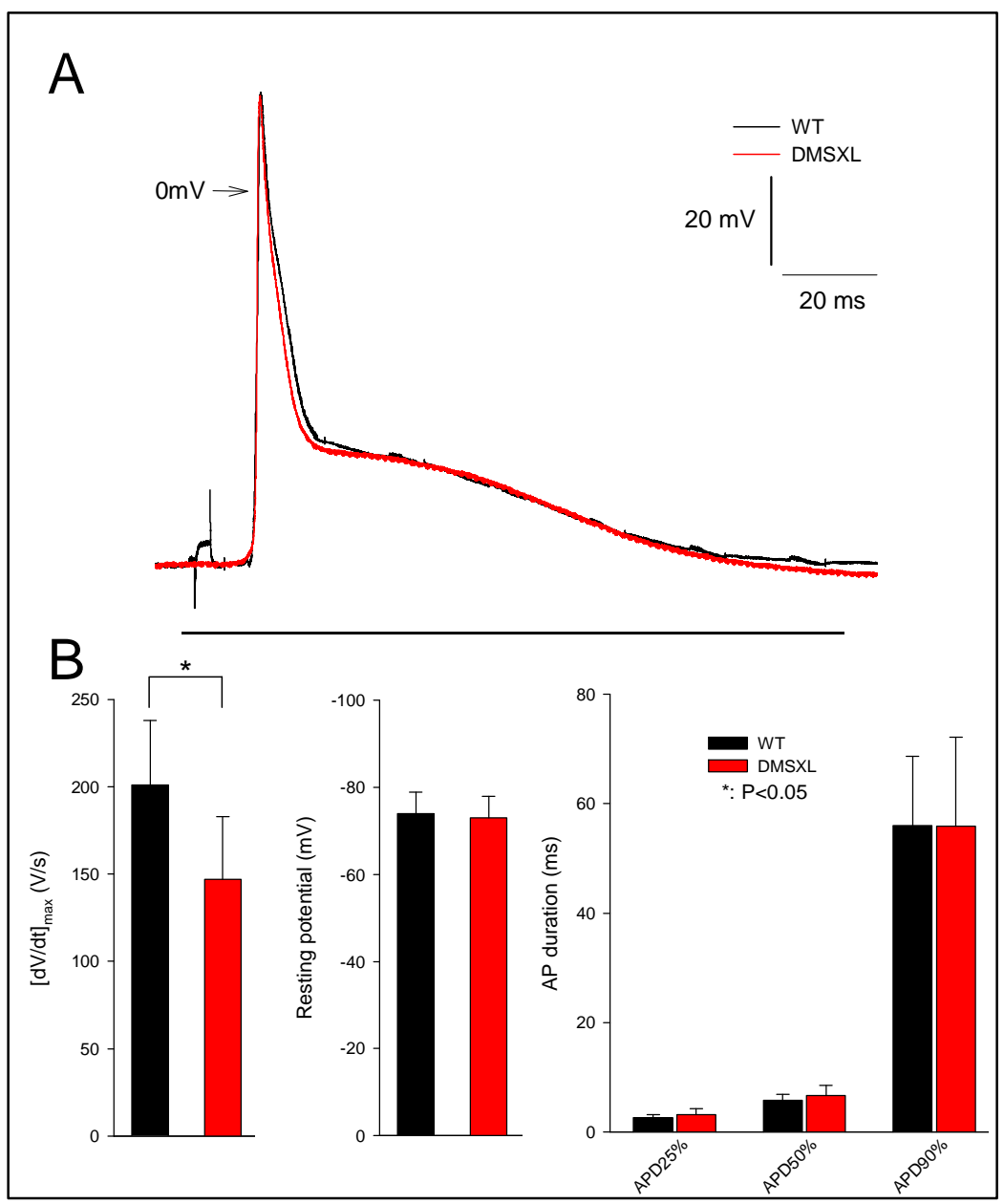


Figure 4:

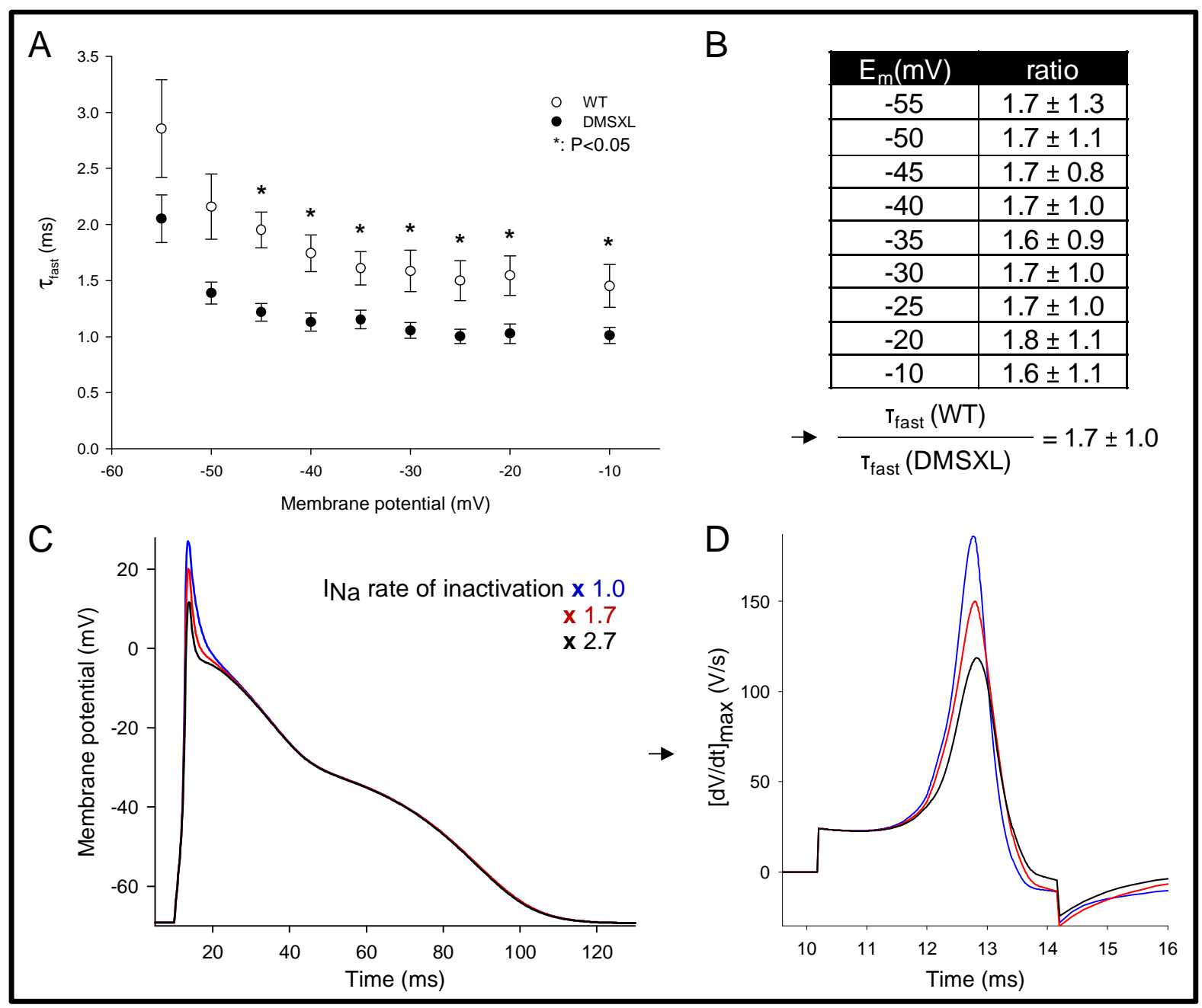


Figure 5:
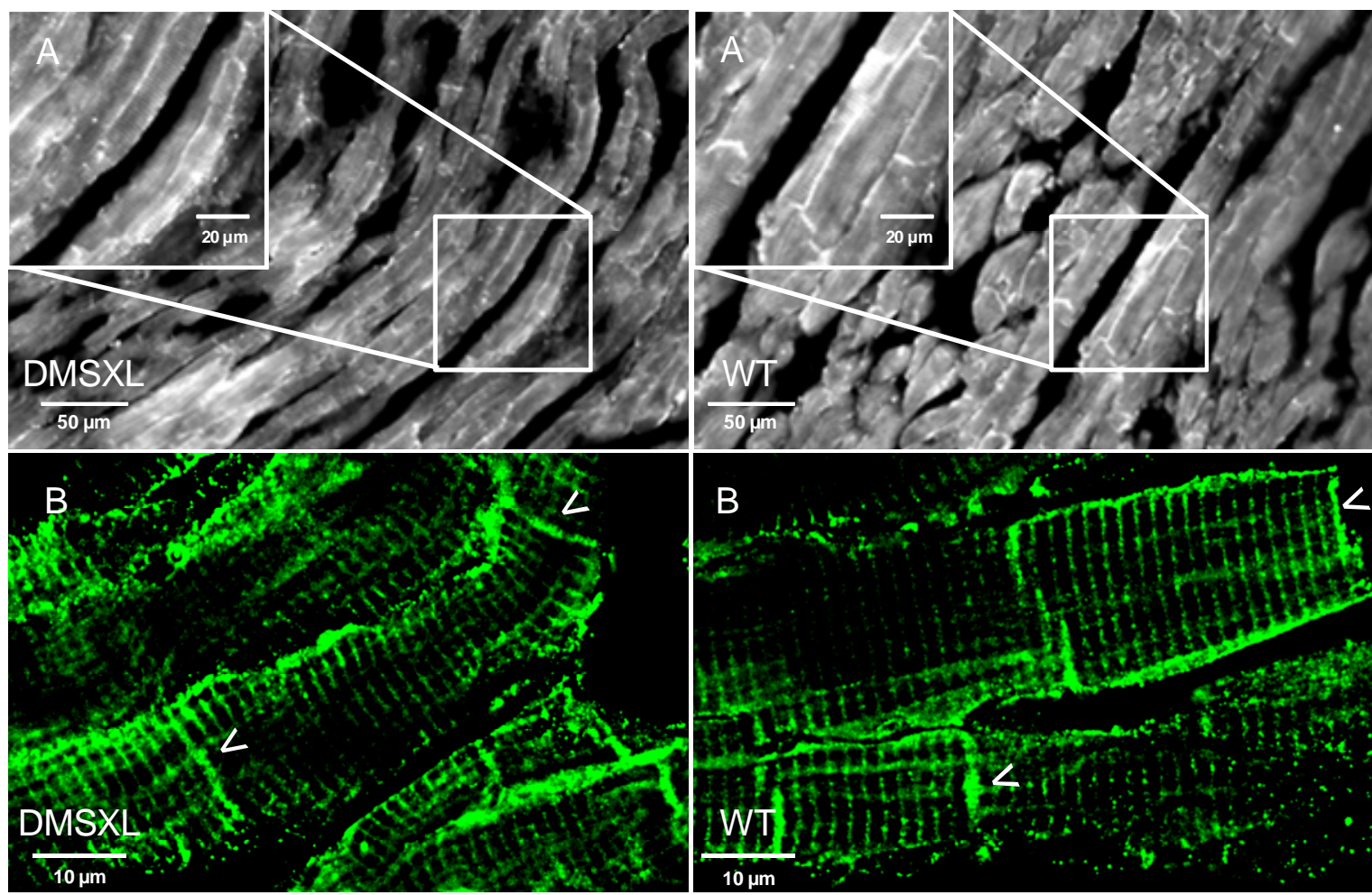

C

DMSXL
C

$\frac{\mathrm{WT}}{50 \mu \mathrm{m}}$ 


\section{Tables:}

Table 1: Electrocardiographic measurements in WT and DMSXL mice aged 3 and 8 months showing the DMSXL phenotype and comparison between WT and DMSXL at baseline and after 16min of flecainide injection.

\begin{tabular}{|c|c|c|c|c|c|c|c|c|c|c|c|}
\hline & \multicolumn{2}{|c|}{3 months } & \multicolumn{2}{|c|}{$\begin{array}{c}3 \text { months } \\
+ \text { flecainide }\end{array}$} & \multirow[b]{2}{*}{$P$} & & \multicolumn{2}{|c|}{8 months } & \multicolumn{2}{|c|}{$\begin{array}{c}8 \text { months } \\
+ \text { flecainide }\end{array}$} & \multirow[b]{2}{*}{$P$} \\
\hline & $\begin{array}{c}\text { WT } \\
(n=9)\end{array}$ & $\begin{array}{c}\text { DMSXL } \\
(n=9)\end{array}$ & $\begin{array}{c}\text { WT } \\
(n=9)\end{array}$ & $\begin{array}{c}\text { DMSXL } \\
(n=9)\end{array}$ & & & $\begin{array}{c}\text { WT } \\
(\mathbf{n}=9)\end{array}$ & $\begin{array}{c}\text { DMSXL } \\
(n=9)\end{array}$ & $\begin{array}{c}\text { WT } \\
(n=9)\end{array}$ & $\begin{array}{c}\text { DMSXL } \\
(\mathbf{n}=9)\end{array}$ & \\
\hline $\mathbf{P}$ & $14 \pm 2$ & $14 \pm 2^{\mathrm{ns}}$ & $22 \pm 2$ & $20 \pm 4^{\mathrm{ns}}$ & 0.72 & $\mathbf{P}$ & $20 \pm 3$ & $24 \pm 4^{\mathrm{ns}}$ & $32 \pm 5$ & $43 \pm 2^{* * * *}$ & $<0.001$ \\
\hline PR & $36 \pm 4$ & $35 \pm 2^{\mathrm{ns}}$ & $45 \pm 3$ & $45 \pm 2^{\mathrm{ns}}$ & 0.64 & PR & $39 \pm 3$ & $39 \pm 4^{\mathrm{ns}}$ & $51 \pm 8$ & $\mathrm{NC}$ & $\mathrm{NC}$ \\
\hline QRS & $11 \pm 1$ & $11 \pm 1^{\mathrm{ns}}$ & $12 \pm 2$ & $15 \pm 3^{\mathrm{ns}}$ & 0.04 & QRS & $13 \pm 2$ & $13 \pm 2^{\text {ns }}$ & $17 \pm 4$ & $25 \pm 3^{* * * *}$ & $<0.001$ \\
\hline QTe & $49 \pm 6$ & $50 \pm 6^{\mathrm{ns}}$ & $64 \pm 8$ & $64 \pm 6^{\mathrm{ns}}$ & 0.93 & QTe & $52 \pm 7$ & $51 \pm 6^{\mathrm{ns}}$ & $59 \pm 7$ & $63 \pm 6^{\mathrm{ns}}$ & 0.68 \\
\hline HR & $454 \pm 91$ & $456 \pm 31^{\mathrm{ns}}$ & $412 \pm 68$ & $424 \pm 44^{\mathrm{ns}}$ & 0.67 & HR & $399 \pm 70$ & $382 \pm 42^{\mathrm{ns}}$ & $360 \pm 82$ & $\mathrm{NC}$ & $\mathrm{NC}$ \\
\hline
\end{tabular}

All values correspond to mean \pm SD and are expressed in milliseconds except for the heart rate (HR in bpm). The ECG was monitored continuously and measurements of the ECG parameters were performed before and after 16 min of flecainide injection. The QTc (corrected QT interval) was calculated following the modified Bazett's formula: QTc $=\mathrm{QT} /(\mathrm{RR} / 100)^{0.5}$. A 2-way ANOVA (Group X Treatment) for repeated measures followed by 2 X 2 comparisons based on Bonferroni test was used. The $P$ column values compare WT vs. DMSXL mice in these tables. Inter-group (before and after flecainide) comparisons between DMSXL and WT are indicated as follow: $* \mathrm{P}<0.05, * * \mathrm{P}<0.01$, $* * * \mathrm{P}<0.001$, ns non significant.

Left table: At 3 months, DMSXL and WT mice had similar ECG parameters. Upon flecainide injection, all ECG parameters are significantly lengthened in the two groups expect for the HR. Flecainide injection affects all ECG parameters but the QRS to the same extent in DMSXL and WT as shown by the non significant $P$ values comparing WT vs. DMSXL mice. The QRS duration was more lengthened by flecainide in DMSXL than in WT mice, even though the 2 X 2 comparison remained non significant.

Right table: At 8 months, DMSXL and WT mice had similar ECG parameters at baseline. Flecainide lengthened more $\mathrm{P}$ wave and QRS interval in DMSXL mice than in WT, reflecting phenotype unmasking in DMSXL upon flecainide.

NC: Not calculated: PR interval and heart rate were not calculated in the groups with second or third degree AV block. 
Table 2: Conventional and tissue Doppler echocardiographic measurements in WT and DMSXL mice aged 3 months at baseline and after flecainide injection (left table) and aged 8 months (right table).

\begin{tabular}{|c|c|c|c|c|c|c|c|c|}
\hline & \multicolumn{2}{|c|}{3 months } & \multicolumn{2}{|c|}{3 months + flecainide } & \multirow[b]{2}{*}{$P$} & \multicolumn{2}{|c|}{8 months } & \multirow[b]{2}{*}{$P$} \\
\hline & $\underset{(\mathbf{n}=10)}{\mathbf{W T}}$ & $\begin{array}{c}\text { DMSXL } \\
(\mathbf{n}=10)\end{array}$ & $\begin{array}{c}\text { WT } \\
(\mathbf{n}=10)\end{array}$ & $\begin{array}{c}\underset{\text { DMSXL }}{(\mathbf{n}=10)} \\
\text { (1) }\end{array}$ & & $\begin{array}{c}\text { WT } \\
(\mathbf{n}=\mathbf{6})\end{array}$ & $\begin{array}{c}\text { DMSXL } \\
(\mathrm{n}=7)\end{array}$ & \\
\hline Heart rate, bpm & $606 \pm 90$ & $586 \pm 92$ & $546 \pm 66$ & $471 \pm 92$ & 0.1 & $615 \pm 110$ & $638 \pm 92$ & 0.8 \\
\hline IVS, mm & $1.1 \pm 0.1$ & $1.0 \pm 0.1$ & $1.0 \pm 0.1$ & $1.0 \pm 0.1$ & 0.9 & $1.04 \pm 0.1$ & $1.0 \pm 0.1$ & 0.4 \\
\hline LVEDD, mm & $2.8 \pm 0.3$ & $2.8 \pm 0.3$ & $2.9 \pm 0.6$ & $2.8 \pm 0.1$ & 0.5 & $2.94 \pm 0.2$ & $2.86 \pm 0.3$ & 0.4 \\
\hline PW, mm & $1.0 \pm 0.1$ & $1.0 \pm 0.1$ & $1.1 \pm 0.1$ & $1.0 \pm 0.1$ & 0.2 & $0.98 \pm 0.1$ & $0.98 \pm 0.1$ & 0.9 \\
\hline LVEF Teichholtz, \% & $87 \pm 2$ & $86 \pm 0.6$ & $86 \pm 4$ & $86 \pm 4$ & 0.8 & $88 \pm 3$ & $86 \pm 4$ & 0.5 \\
\hline Shortening fraction, \% & $51 \pm 4$ & $50 \pm 0.9$ & $50 \pm 6$ & $50 \pm 5$ & 0.8 & $53 \pm 4$ & $50 \pm 5$ & 0.5 \\
\hline Mitral E wave, m/s & $0.7 \pm 0.1$ & $0.8 \pm 0.1$ & $0.8 \pm 0.1$ & $0.8 \pm 0.1$ & 0.7 & $0.9 \pm 0.1$ & $0.9 \pm 0.1$ & 0.8 \\
\hline$S$ wave endo, $\mathrm{cm} / \mathrm{s}$ & $2.7 \pm 0.4$ & $2.5 \pm 0.4$ & $2.6 \pm 0.3$ & $2.0 \pm 0.3^{* *}$ & 0.04 & $3.6 \pm 0.4$ & $2.9 \pm 0.1$ & 0.003 \\
\hline S wave epi, cm/s & $1.8 \pm 0.4$ & $1.5 \pm 0.3$ & $1.9 \pm 0.7$ & $1.1 \pm 0.4^{* *}$ & 0.001 & $3.2 \pm 0.5$ & $2.6 \pm 0.2$ & 0.02 \\
\hline Strain rate $S$ wave, $1 / \mathrm{s}$ & $12.6 \pm 1.7$ & $11.8 \pm 1.3$ & $12.2 \pm 2.6$ & $9.9 \pm 1.3^{*}$ & 0.03 & $18.0 \pm 0.9$ & $13.7 \pm 4.0$ & 0.03 \\
\hline
\end{tabular}

Values are means \pm SD. IVS: intraventricular septum thickness; LVEDD: left ventricular end diastolic diameter; PW: posterior wall; S wave: systolic wave; bpm: beats per minute. Because echocardiographic parameters present high variations according to the heart rate, they were not measured in the 8-month-old mice group with high incidence of AV block and bradycardia.

Left table: A 2-way ANOVA (Group X Treatment) for repeated measures followed by post-hoc Bonferroni test was used. The $P$ column values compare WT vs. DMSXL mice in this table. At 3 months, there is no significant difference between DMSXL and WT mice in baseline conditions. However, flecainide injection reveals a reduced $S$ wave endo, $S$ wave epi and Strain rate $S$ wave in DMSXL mice compared to WT. Intergroup comparisons before and after flecainide injections are indicated as follow: $* \mathrm{P}<0.05 ; * * \mathrm{P}<0.01$.

Right table: 1-way ANOVA (Group) followed by 2 X 2 comparisons based on Bonferroni test was used. The $P$ column values compare WT vs. DMSXL mice at 8 months. 
Table 3: Action potential and sodium current parameters from 8-month-old DMSXL and WT mice.

\begin{tabular}{|c|c|c|c|}
\hline & $\begin{array}{c}\text { WT } \\
(\mathrm{N}=4)\end{array}$ & $\begin{array}{c}\text { DMSXL } \\
(\mathrm{N}=4)\end{array}$ & $\boldsymbol{P}$ \\
\hline Action potential recordings & $(n=17)$ & $(n=65)$ & \\
\hline Resting potential, $\mathrm{mV}$ & $-74(-79 ;-70)$ & $-72(-75 ;-69)$ & 0.32 \\
\hline$[\mathrm{dV} / \mathrm{dt}]_{\max }, \mathrm{V} / \mathrm{s}$ & $195(173 ; 226)$ & $135(125 ; 164)$ & $<0.001$ \\
\hline \multicolumn{4}{|l|}{ Action potential duration (ms): } \\
\hline $25 \%$ & $2.7 \pm 0.5$ & $3.2 \pm 1.1$ & 0.17 \\
\hline $50 \%$ & $5.9 \pm 1.0$ & $6.7 \pm 1.8$ & 0.21 \\
\hline $90 \%$ & $56 \pm 13$ & $56 \pm 16$ & 0.56 \\
\hline Sodium current & $(n=16)$ & $(n=22)$ & \\
\hline Membrane capacitance (pF) & $155 \pm 47$ & $122 \pm 33$ & 0.02 \\
\hline Peak $\mathrm{Na}^{+}$current, $\mathrm{pA} / \mathrm{pF}(-20 \mathrm{mV})$ & $-71 \pm 33$ & $-73 \pm 33$ & 0.8 \\
\hline $\mathrm{V}_{0.5}$ of activation- $\mathrm{V}_{\mathrm{m}}$ relationship, $\mathrm{mV}$ & $-48.9 \pm 5.1$ & $-48.3 \pm 4.5$ & 0.8 \\
\hline $\mathrm{V}_{0.5}$ of availability- $\mathrm{V}_{\mathrm{m}}$ relationship, $\mathrm{mV}$ & $-83.4 \pm 6.9$ & $-83.1 \pm 5.2$ & 0.6 \\
\hline $\mathrm{t}_{1 / 2}, \mathrm{~ms}(-20 \mathrm{mV})$ & $1.8 \pm 0.4$ & $1.4 \pm 0.5$ & 0.01 \\
\hline$\tau_{\text {fast }},(\mathrm{ms})(-20 \mathrm{mV})$ & $1.7 \pm 0.6$ & $1.0 \pm 0.3$ & 0.004 \\
\hline
\end{tabular}

Data are expressed as means \pm SD for continuous variables or median (25\% and $75 \%$ interquartiles) as requested. $\mathrm{N}$ : number of mice used for each experiment, $\mathrm{V}_{0.5}$ : half value of activation / availability $-\mathrm{V}_{\mathrm{m}}$ relationships of the sodium current in steady state protocol, $\mathrm{t}_{1 / 2}$ : time of half inactivation of the sodium current, $[\mathrm{dV} / \mathrm{dt}]_{\max }$ : maximum upstroke of the 0 phase of the action potential. 


\section{Translational Impact}

\section{Clinical issue:}

The multisystemic autosomal dominant disorder myotonic dystrophy type 1 (DM1), also known as Steinert's disease, is the commonest form of adult-onset muscular dystrophy. DM1 is caused by abnormal expansion of CTG trinucleotide repeats in the gene encoding the DM protein kinase $D M P K$. Cardiac arrhythmia and conduction blocks are the major and potentially life-threatening feature of patients with DM1 such as one third of patients with DM1 die suddenly. However, the underlying mechanisms of these cardiac electrical conductions disturbances are not known except that acute induction of CTC repeats causes conduction block in mice.

\section{Results:}

Given the impossibility to perform experimental study using human myocardium of patients with DM1, animal models are crucial to underpin the pathophysiology of this disease. Here we used a unique mice model carrying a long CTG repeat in the DMPK gene resulting in a slow and chronic accumulation of CTG repeats as observed in human, to study cardiac abnormalities associated with the development of the disease. Pharmacological stress test using a sodium channel blocker revealed a high incidence of atrioventricular conduction blocks and impaired left ventricle function in DMSXL mice that progressed with ageing. These results suggested abnormal sodium current properties as a common mechanism for electrical and contractile dysfunction. Indeed, the sodium current recorded using the patch clamp technique in isolated myocytes showed a 1.7 fold faster current inactivation rate in DMSXL than in WT myocytes. Ventricular action potential (AP) recordings and computer model indicated that this shortened sodium current could account partly for the slow AP and depressed excitability of DM1 myocardium. No structural myocardial abnormalities or default of channel expression could explain this current abnormality.

\section{Implications and future directions:}

This study reveals a totally new mechanism responsible for the conduction block and contractile 
dysfunction in DM1 which could modify the prevention and treatment of the risk of sudden death and heart failure in DM1 patients. For instance, the enhanced sensitivity to the antiarrhythmic drugs affecting the cardiac sodium current should have therapeutic implications. In addition, this study provides another example of a complex disease associated with discrete changes of the sodium current properties. It points out to the possibility of a continuum of diseases from pure channelopathies to neuromuscular disorders and cardiomyopathy. These results justify further study to underpin the molecular basis of sodium current dysfunction in DM1. 